\title{
Density, viscosity and ultrasonic speed based acoustical studies of structural properties of 1, 1'-bis (4-amino phenyl) cyclohexane symmetric double Schiff bases in THF solutions at 303.15, 308.15 and 313.15K
}

\author{
Bhavesh J. Gangani ${ }^{1}$, Parsotam H. Parsania ${ }^{2^{\star}}$ \\ ${ }^{1}$ Shree M. P. Shah Arts \& Science College, Surendranagar-363001, Gujarat, India \\ ${ }^{2}$ Department of Chemistry, Saurashtra University, Rajkot-360 005, Gujarat, India \\ 1,2E-mail id: bj2gangani@gmail.com, phparsania22@gmail.com,
}

Keywords: Ultrasonic speed, density, viscosity, symmetric double Schiff bases, molecular interactions and solvation number

\begin{abstract}
The density ( $\rho$ ), viscosity $(\eta)$ and ultrasonic speed (U) (2MHz) of THF solutions of symmetric double Schiff bases (SDSB-1,SDSB-2 and SDSB-3) were determined at 303.15, 308.15 and $313.15 \mathrm{~K}$. Various acoustical parameters such as specific acoustical impedance (Z), isentropic compressibility $\left(\kappa_{\mathrm{s}}\right)$, Rao's molar sound function $\left(\mathrm{R}_{\mathrm{m}}\right)$, Van der Waals constant (b), internal pressure $(\pi)$, free volume $\left(V_{f}\right)$, intermolecular free path length $\left(\mathrm{L}_{\mathrm{f}}\right)$, viscous relaxation time $(\tau)$ and classical absorption coefficient $\left.\left(\alpha / \mathrm{f}^{2}\right)_{\mathrm{Cl}}\right)$, were determined using $\rho, \eta$ and $U$ data. The results are interpreted in terms of molecular interactions occurring in the solutions at different temperatures and concentrations. Linear increase of $\rho, \eta \mathrm{U}, \mathrm{Z}, \mathrm{R}_{\mathrm{m}}, \mathrm{b},\left(\alpha / \mathrm{f}^{2}\right)_{\mathrm{Cl}}$ and $\tau$ with increasing $\mathrm{C}$, linear decrease of $K_{S}, L_{f}$ and $\pi$ with increasing $T, V_{f}$ increased linearly with $C$ and $T$ except SDSB-3 supported existence of strong molecular interactions in the solutions and confirming solvophilic nature of the Schiff bases. The structure, nature and size of the solutes and solvent, concentration and temperature affected molecular interactions.
\end{abstract}

\section{INTRODUCTION}

Symmetric double Schiff bases or imines or azomethines have played vital role in the progress of chemical sciences [1]. Symmetric double Schiff bases or bis Schiff bases are synthesized by acid catalyzed condensation of aromatic or aliphatic primary diamines with aromatic aldehydes by conventional and microwave irradiation methods [2-4]. Schiff bases are well known due to their wide range of applications such as a corrosion inhibitors [5], analytical reagents, catalyst, catalysis, for synthesis of metal complexes and additives in synthetic lubricant [6]. Schiff bases are most widely used as pigments, dyes, polymer stabilizers and intermediate in organic synthesis [7]. Schiff bases and their metal complexes have attracted a lot of interest due to their potent biological activities such as antifungal, antibacterial, antimicrobial [8], antitumor, anticancer [9], anti-inflammatory, antiphlogistic, anti-HIV activities and antidepressant [10].

Ultrasonic technique is one of the most useful techniques to study the molecular interactions in the solution; so many scientists have observed close relation between ultrasonic velocity and chemical or structural characteristic of molecule of fluid [11-13]. The ultrasonic velocity and viscosity measurements have proved important for studying molecular and structural properties of liquid solution [14]. Therefore by measuring density of liquid and its ultrasonic velocity many acoustical parameters can be determined [15]. Acoustical parameters provide information about molecular interactions, the nature and strength of interactions, solute-solute and solute-solvent interactions in pure solvents and theirs solutions [16-17]. Drug action is affected by various kinds of physico-chemical interactions e.g. ionic or covalent, charge-transfer, hydrogen bonding, ionicdipole interaction, hydrophilic interaction [18], which can be understood by thermo physical and transport properties [19] e.g. ultrasonic velocity, viscosity and thermal conductivity. The uses of 
drugs involved physiological and biological effect and their mechanism of action at macromolecular, sub cellular organ system. Various pharmacokinetics processes involves transport of drugs across biological membrane, which can be understood by transport property e.g. ultrasonic speed, viscosity diffusion and thermal conductivity [20,21].

In continuation of ultrasonic study of symmetric double Schiff bases [22, 23] in this paper we have reported determination of density, viscosity and ultrasonic speed of the solution of symmetric doubleSchiff bases of 1,1'-bis (4-amino phenyl)cyclohexane (Scheme-I)in THF at 303.15, 308.15 and 313.15 Kand at different concentrations. Various acoustical parameters have been determined and discussed to understand molecular interactions in the solutions.

\section{EXPERIMENTAL AND MEASUREMENTS}

THF used in the present study was supplied by Allied Chemical Corporation Vadodara, and purified according to literature method [24]. THF is cyclic ether have IUPAC name oxolane, $\rho$ $=0.8892 \mathrm{~g} / \mathrm{cm}^{3}$ at $298.15 \mathrm{~K}$, molecular shape- envelope, dipole moment $1.63 \mathrm{D}$ with low viscosity. Schiff bases SDSB-1, SDSB-2 and SDSB-3 (Scheme-I) were synthesized and crystallized according to our previous work [3].The stock Schiff bases solutions $(0.10 \mathrm{~mol})$ were prepared and from them a series of solutions were prepared. The solutions were stored in air tight flasks.

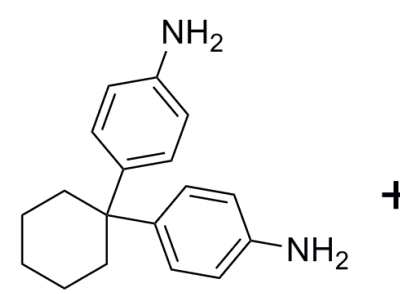

$0.01 \mathrm{~mol}$

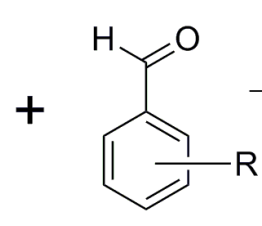

0.021
EtOH
Glacial acetic acid

Reflux 7.5-3 h

Scheme -I

SDSB-2 $\mathrm{R}=-2 \mathrm{NO}_{2}$

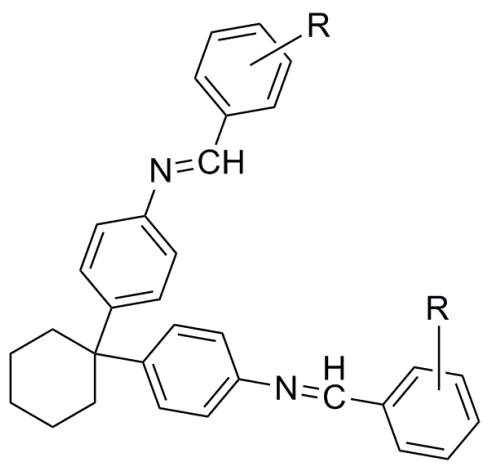

SDSB-1 to 3

SDSB-1 R= 2-OCH

The density $(\rho)$ measurements were performed for different solutions at 303.15, 308.15 and $313.15 \mathrm{~K} \pm 0.1 \mathrm{~K}$ with the help of specific gravity bottle. The estimated errors in density measurements were found to be $\pm 0.1 \mathrm{~kg} / \mathrm{m}^{3}$ as reported in our earlier work $[15,16]$. Viscosity $(\eta)$ and ultrasonic speed (U) of Schiff bases solutions (SDSB-1 to 3) were measured with an Ubbelohde suspended level viscometer and Mittal Enterprise Interferometer (New Delhi) Model No F-81, operating at $2 \mathrm{MHz}$ at $303.15,308.15$ and $313.15 \mathrm{~K} \pm 0.1 \mathrm{~K}$ respectively. The $\eta$ and $U$ measurements were accurate to $0.01 \mathrm{~m} \mathrm{~Pa} \mathrm{~s}$ and $\pm 0.15 \%$, respectively as described in our earlier paper [22, 23]. Various thermodynamic parameters have been evaluated from the experimental values of $\rho \eta$ and $U$ data.

\section{RESULTS AND DISCUSSION}

The $\rho, \eta$ and U of THF and SDSB- 1 to SDSB-3 solutions are reported in Table 1. Acoustical properties are of great signification in studying the physico-chemical behavior and molecular interactions of component of solutions. The molecular interactions exist in Schiff bases solutions in THF are discussed in terms ofacoustical parameters. Various acoustical parameters such as specific acoustical impedance $(Z)$, isentropic compressibility $\left(\kappa_{\mathrm{s}}\right)$, Rao's molar sound function $\left(\mathrm{R}_{\mathrm{m}}\right)$, Vander Waals constant $(b)$, intermolecular free path length $\left(\mathrm{L}_{\mathrm{f}}\right)$, internal pressure $(\pi)$, free volume $\left(\mathrm{V}_{\mathrm{f}}\right)$, 
viscous relaxation time $(\tau)$, classical absorption coefficient $\left(\alpha / \mathrm{f}^{2}\right)_{\mathrm{Cl}}$ and solvation number $\left(\mathrm{S}_{\mathrm{n}}\right)$ of Schiff bases solutions were derived according to our previous work [15, 22] and are reported in Table 2. All these parameters were correlated with concentration $(C)$ of Schiff bases at different temperatures $(\mathrm{T})$.

Table-1 The density ( $\rho)$, viscosity ( $\eta$ ) and sound velocity (U) of SDSB-1, SDSB-2 and SDSB-3 at $303.15,308.15$ and $313.15 K$

\begin{tabular}{|c|c|c|c|c|c|c|c|c|c|}
\hline $\begin{array}{r}\text { Conc., } \\
\mathbf{m o l} / \mathbf{d m}^{3}\end{array}$ & $\begin{array}{c}\text { Density } \\
\rho, \\
\mathrm{kg} / \mathrm{m}^{3}\end{array}$ & $\begin{array}{c}\text { Viscosity } \\
\eta \cdot \\
10^{3}, \mathrm{~Pa} \mathrm{~s} \\
\end{array}$ & $\underset{\mathbf{m s}^{-1}}{\mathbf{U}}$ & $\begin{array}{c}\text { Density } \\
\rho, \\
\mathrm{kg} / \mathrm{m}^{3} \\
\end{array}$ & $\begin{array}{c}\text { Viscosity } \\
\eta \cdot \\
10^{3}, \text { Pa s } \\
\end{array}$ & $\underset{\mathbf{m s}^{-1}}{\mathbf{U}}$ & $\begin{array}{c}\text { Density } \\
\rho, \\
\mathrm{kg} / \mathrm{m}^{3} \\
\end{array}$ & $\begin{array}{c}\text { Viscosity } \\
\eta \cdot \\
10^{3}, \text { Pa s } \\
\end{array}$ & $\underset{\mathbf{m s}^{-1}}{\mathbf{U}}$ \\
\hline \multicolumn{4}{|c|}{ THF-SDSB-1 at $303.15 \mathrm{~K}$} & \multicolumn{3}{|c|}{ THF-SDSB-2 at 303.15K } & \multicolumn{3}{|c|}{ THF-SDSB-3 at 303.15K } \\
\hline 0 & 882.3 & 0.470 & 1263.8 & 882.3 & 0.467 & 1263.8 & 882.3 & 0.470 & 1263.8 \\
\hline 0.01 & 888.9 & 0.543 & 1277.2 & 886.3 & 0.504 & 1265.0 & 886.5 & 0.476 & 1265.8 \\
\hline 0.02 & 892.1 & 0.566 & 1283.2 & 888.9 & 0.534 & 1275.2 & 889.5 & 0.482 & 1269.0 \\
\hline 0.04 & 895.4 & 0.604 & 1289.4 & 892.7 & 0.562 & 1280.2 & 893.1 & 0.517 & 1272.2 \\
\hline 0.06 & 898.6 & 0.631 & 1296.6 & 895.9 & 0.579 & 1287.0 & 896.0 & 0.549 & 1276.6 \\
\hline 0.08 & 900.7 & 0.670 & 1303.4 & 898.0 & 0.604 & 1293.0 & 898.3 & 0.589 & 1281.4 \\
\hline 0.10 & 902.7 & 0.694 & 1309.6 & 900.7 & 0.631 & 1299.0 & 900.5 & 0.626 & 1285.4 \\
\hline \multicolumn{4}{|c|}{ THF-SDSB-1 at 308.15K } & \multicolumn{3}{|c|}{ THF-SDSB-2 at 308.15K } & \multicolumn{3}{|c|}{ THF-SDSB-3 at 308.15K } \\
\hline $\mathbf{0}$ & 881.8 & 0.446 & 1233.6 & 881.8 & 0.446 & 1233.6 & 881.8 & 0.446 & 1233.6 \\
\hline 0.01 & 887.9 & 0.478 & 1249.4 & 885.4 & 0.464 & 1243.4 & 884.8 & 0.451 & 1255.4 \\
\hline 0.02 & 891.2 & 0.492 & 1255.6 & 888.0 & 0.487 & 1249.2 & 887.7 & 0.464 & 1259.0 \\
\hline 0.04 & 894.4 & 0.541 & 1263.4 & 891.5 & 0.506 & 1257.0 & 891.6 & 0.487 & 1263.6 \\
\hline 0.06 & 897.5 & 0.579 & 1268.8 & 893.9 & 0.524 & 1262.8 & 893.7 & 0533 & 1267.2 \\
\hline 0.08 & 899.5 & 0.625 & 1275.4 & 896.1 & 0.559 & 1269.2 & 896.9 & 0.572 & 1272.4 \\
\hline 0.10 & 902.1 & 0.657 & 1280.8 & 897.9 & 0.595 & 1275.2 & 898.1 & 0.593 & 1279.2 \\
\hline \multicolumn{4}{|c|}{ THF-SDSB-1 at 313.15K } & \multicolumn{3}{|c|}{ THF-SDSB-2 at 313.15K } & \multicolumn{3}{|c|}{ THF-SDSB-3 at 313.15K } \\
\hline $\mathbf{0}$ & 881.2 & 0.429 & 1216.8 & 881.2 & 0.429 & 1216.8 & 881.2 & 0.429 & 1216.8 \\
\hline 0.01 & 882.9 & 0.431 & 1235.4 & 884.6 & 0.453 & 1220.4 & 883.9 & 0.437 & 1233.4 \\
\hline 0.02 & 886.3 & 0.460 & 1241.8 & 887.2 & 0.467 & 1229.2 & 886.0 & 0.456 & 1235.0 \\
\hline 0.04 & 889.9 & 0.503 & 1247.0 & 890.1 & 0.487 & 1235.2 & 888.3 & 0.475 & 1239.6 \\
\hline 0.06 & 892.3 & 0.541 & 1256.0 & 892.7 & 0.507 & 1240.6 & 891.5 & 0.498 & 1245.2 \\
\hline 0.08 & 895.0 & 0.580 & 1261.2 & 895.1 & 0.531 & 1247.2 & 893.8 & 0.557 & 1251.4 \\
\hline 0.10 & 897.3 & 0.615 & 1265.0 & 896.5 & 0.562 & 1253.0 & 896.6 & 0.574 & 1256.6 \\
\hline
\end{tabular}

From Table 1, it is evident the $\rho, \eta$ and $U$ increased with $C$ and decreased with T suggested powerful solute-solvent interactions. The increase of $\rho$ led to quick transfer of sound velocity and hence $U$ increased with increasing $C$. The law of additivity is observed in present case confirming that the density of Schiff bases is greater than that of THF. The viscosity $(\eta)$ of the solvent and solutions are measure of cohesiveness or rigidity present between components of the solutions. The variation of $\eta$ and $U$ with $C$ and $T$ are considerably more than $\rho$ due to specific solute and solvent interactions. The nature of solute and solvent play an important role in molecular interactions such as ionic-covalent, inter-intra molecular H-bonding, dipole-dipole interaction, weak van der waals force of attraction as well as London forces. The $\eta$ increased linearly with increasing $\mathrm{C}$ confirmed existence of strong molecular interactions in the solution [25]. The decrease of $\eta$ with increasing in temperature showing that solute-solvent interaction is influenced by the temperature. Thus Schiff bases molecule can labeled as structure makers in THF solutions. 
From Table 2 to 5 , it is observed that in THF, Z ( $\gamma=0.989$ to 0.999$)$ increased linearly with $\mathrm{C}$ and decreased with $\mathrm{T}$, while $\kappa_{\mathrm{s}}(\gamma=-0.986$ to -0.999$)$ and $\mathrm{L}_{\mathrm{f}}(\gamma=-0.987$ to -0.998$)$ decreased linearly with increasing $\mathrm{C}$ and increased with $\mathrm{T}$. The increasing trend of $\mathrm{Z}$ supported the molecular interactions. $Z$ is directly proportional to $U$ and inversely proportional to $\kappa_{\mathrm{s}}$. The predominance of particular solute-solute or solute-solvent interaction can be detected by $\kappa_{\mathrm{s}}$. The decrease in $\kappa_{\mathrm{s}}$ with increase in $\mathrm{C}$ is due to aggregation of solvent molecules around solute molecules indicating presences of solute-solvent interaction. This phenomenon can be explained by assuming that the solvated molecules are fully compressed by the electric force of the ions. The $\kappa_{\mathrm{s}}$ of solution is mainly due to free solvent molecules but due to solute-solvent interaction $\kappa_{\mathrm{s}}$ of solution decrease with increase in concentration. The decrease of $\mathrm{L}_{\mathrm{f}}$ with $\mathrm{C}$ increase in sound velocity and vice versa supported strong solute-solvent interactions. The linear change in $\mathrm{R}_{\mathrm{m}}(\gamma=0.993$ to 1.000$)$ and $\mathrm{b}(\gamma=$ 0.999 to 1.000$)$ suggested the absence of any complex formation in THF system. $V_{f}(\gamma=-0.846$ to $0.993)$ increased linearly with increasing in C and T except SDSB-3. The internal pressure $(\pi)$ is the result of forces of attraction and repulsion between molecules in solutions. From Table 2 to $5 \pi$ ( $\gamma=$ - 0.983 to -0.998 ) decreased linearly with increasing $\mathrm{C}$ and decreased with $\mathrm{T}$. The decrease in $\pi$ indicates the loosening of cohesive forces leading breaking of structure formed and indicated existence of solute-solute interaction in THF solution at higher concentration and temperature. This is further supported by a free volume $\left(\mathrm{V}_{\mathrm{f}}\right)$. Free volume of solute molecule at constant temperature and pressure depend on the internal pressure of liquid in which it is dissolved. The decrease in $\pi$ caused increase in $V_{\mathrm{f}}$ which is an inverse function of $\pi$.

From Table 2 to $5\left(\alpha / \mathrm{f}^{2}\right)_{\mathrm{Cl}}(\gamma=0.979$ to 0.997$)$ and $\tau(\gamma=0.985$ to 0.998$)$ increased linearly with $\mathrm{C}$ and decreased with T. $\left(\alpha / \mathrm{f}^{2}\right)_{\mathrm{cl}}$ and $\tau$ are dependent on $\rho, \eta$ and $\mathrm{U}$ at constant temperature. Increase of $\left(\alpha / \mathrm{f}^{2}\right)_{\mathrm{cl}}$ and $\tau$ with $\mathrm{C}$ can be explained in terms of motion of intermolecular forces. A contribution of acoustical relaxation is accounted due to entropy fluctuation associated in solution of dynamically formed physical entity. The presences of polar groups in the solute molecule enhance molecular interactions. Thus, various acoustical parameters suggested solute-solute and solute-solvent interaction in THF solutions. Solvation number $\left(S_{n}\right)$ [26] the number of grams of solvent molecules connected in the apparent solvation of $1 \mathrm{~g}$ of solute-assuming the solvent molecules participating in the solvation are effectively incompressible due to strong localized electronic fields is expressed as:

$$
S_{n}=\frac{M_{2}}{M_{1}\left(1-\kappa_{s} / \kappa_{s_{1}}\right)\left(\frac{100-X}{X}\right)}
$$

Where $\mathrm{X}$ is the number of grams of solute in $100 \mathrm{~g}$ of the solution 
Table-2 Acoustical parameters of SDSB-1, SDSB-2 and SDSB-3 in THF solutions at 303.15, 308.15 and $313.15 \mathrm{~K}$

\begin{tabular}{|c|c|c|c|c|c|c|c|c|c|}
\hline \multirow{2}{*}{$\begin{array}{l}\text { Conc., } \\
\text { mol/ lit }\end{array}$} & 303.15K & $308.15 K$ & 313.15K & 303.15K & $308.15 K$ & $313.15 K$ & $303.15 K$ & $308.15 K$ & 313.15K \\
\hline & \multicolumn{3}{|c|}{ SDSB-1 } & \multicolumn{3}{|c|}{ SDSB-2 } & \multicolumn{3}{|c|}{ SDSB-3 } \\
\hline & \multicolumn{3}{|c|}{$\mathrm{Z} \times 10^{-6}, \mathrm{~kg} \cdot \mathrm{m}^{-2} \mathrm{~s}^{-1}$} & \multicolumn{3}{|c|}{$\mathrm{Z} \times 10^{-6}, \mathrm{~kg} \cdot \mathrm{m}^{-2} \mathrm{~s}^{-1 \mathrm{~S}}$} & \multicolumn{3}{|c|}{$\mathrm{Z} \times 10^{-6}, \mathrm{~kg} \cdot \mathrm{m}^{-2} \mathrm{~s}^{-1 \mathrm{~S}}$} \\
\hline 0.0 & 1.115 & 1.088 & 1.072 & 1.115 & 1.088 & 1.072 & 1.115 & 1.088 & 1.072 \\
\hline 0.01 & 1.135 & 1.109 & 1.091 & 1.121 & 1.101 & 1080 & 1.122 & 1.111 & 1.090 \\
\hline 0.02 & 1.145 & 1.119 & 1.101 & 1.134 & 1.109 & 1.091 & 1.129 & 1.118 & 1.094 \\
\hline 0.04 & 1.155 & 1.130 & 1.110 & 1.143 & 1.121 & 1.099 & 1.136 & 1.127 & 1.101 \\
\hline 0.06 & 1.165 & 1.139 & 1.121 & 1.153 & 1.129 & 1.107 & 1.144 & 1.132 & 1.110 \\
\hline 0.08 & 1.174 & 1.147 & 1.129 & 1.161 & 1.137 & 1.116 & 1.151 & 1.141 & 1.119 \\
\hline \multirow[t]{2}{*}{0.10} & 1.182 & 1.155 & 1.135 & 1.170 & 1.145 & 1.123 & 1.158 & 1.149 & 1.127 \\
\hline & \multicolumn{3}{|c|}{$\kappa_{\mathrm{S}} \times 10^{+10}, \mathrm{~Pa}^{-1}$} & \multicolumn{3}{|c|}{$\kappa_{\mathrm{S}} \times 10^{+10}, \mathrm{~Pa}^{-1}$} & \multicolumn{3}{|c|}{$\kappa_{\mathrm{S}} \times 10^{+10}, \mathrm{~Pa}^{-1}$} \\
\hline 0.0 & 7.096 & 7.452 & 7.665 & 7.096 & 7.452 & 7.665 & 7.096 & 7.452 & 7.665 \\
\hline 0.01 & 6.987 & 7.215 & 7.422 & 7.051 & 7.305 & 7.590 & 7.040 & 7.171 & 7.437 \\
\hline 0.02 & 6.808 & 7.117 & 7.317 & 6.918 & 7.216 & 7.460 & 6.981 & 7.107 & 7.400 \\
\hline 0.04 & 6.717 & 7.055 & 7.227 . & 6.835 & 7.099 & 7.364 & 6.918 & 7.024 & 7.326 \\
\hline 0.06 & 6.619 & 6.921 & 7.104 & 6.739 & 7.015 & 7.278 & 6.848 & 6.968 & 7.235 \\
\hline 0.08 & 6.535 & 6.835 & 7.025 & 6.661 & 6.928 & 7.182 & 6.780 & 6.887 & 7.144 \\
\hline \multirow[t]{2}{*}{0.10} & 6.459 & 6.757 & 6.964 & 6.580 & 6.849 & 7.105 & 6.721 & 6.805 & 7.063 \\
\hline & \multicolumn{3}{|c|}{$\mathrm{R}_{\mathrm{m}} \times 10^{4}, \mathrm{~m}^{10 / 3} \mathrm{~s}^{1 / 3} \mathrm{~mol}^{-1}$} & \multicolumn{3}{|c|}{$\mathrm{R}_{\mathrm{m}} \times 10^{4}, \mathrm{~m}^{10 / 3} \mathrm{~s}^{1 / 3} \mathrm{~mol}^{-1}$} & \multicolumn{3}{|c|}{$\mathrm{R}_{\mathrm{m}} \times 10^{4}, \mathrm{~m}^{10 / 3} \mathrm{~s}^{1 / 3} \mathrm{~mol}^{-1}$} \\
\hline 0.0 & 8.834 & 8.768 & 8.734 & 8.834 & 8.768 & 8.734 & 8.834 & 8.768 & 8.734 \\
\hline 0.01 & 9.096 & 9.040 & 9.059 & 9.134 & 9.091 & 9.043 & 9.134 & 9.127 & 9.083 \\
\hline 0.02 & 9.371 & 9.313 & 9.333 & 9.466 & 9.412 & 9.370 & 9.444 & 9.440 & 9.399 \\
\hline 0.04 & 9.935 & 9.880 & 9.893 & 10.102 & 10.056 & 10015 & 10.076 & 10.072 & 10.050 \\
\hline 0.06 & 10.497 & 10.436 & 10.471 & 10.742 & 10.703 & 10.656 & 10.712 & 10.718 & 10.687 \\
\hline 0.08 & 11.067 & 11.005 & 11.031 & 11.390 & 11.349 & 11.299 & 11.351 & 11.346 & 11.332 \\
\hline \multirow[t]{2}{*}{0.10} & 11.634 & 11.558 & 11.581 & 12.023 & 11.997 & 11.951 & 11.984 & 12.006 & 11.960 \\
\hline & \multicolumn{3}{|c|}{$\mathrm{b} \times 10^{5}, \mathrm{~m}^{3}$} & \multicolumn{3}{|c|}{$\mathrm{b} \times 10^{5}, \mathrm{~m}^{3}$} & \multicolumn{3}{|c|}{$\mathrm{b} \times 10^{5}, \mathrm{~m}^{3}$} \\
\hline 0.0 & 8.041 & 8.044 & 8.048 & 8.039 & 8.042 & 8.047 & 8.039 & 8.042 & 8.047 \\
\hline 0.01 & 8.252 & 8.260 & 8.307 & 8.311 & 8.318 & 8.325 & 8.309 & 8.325 & 8.332 \\
\hline 0.02 & 8.490 & 8.497 & 8.546 & 8.592 & 8.601 & 8.607 & 8.586 & 8.604 & 8.620 \\
\hline 0.04 & 8.989 & 8.999 & 9.048 & 9.161 & 9.173 & 9.188 & 8.156 & 9.172 & 9.209 \\
\hline 0.06 & 9.483 & 9.495 & 9.558 & 9.728 & 9.752 & 9.765 & 9.725 & 9.754 & 9.780 \\
\hline 0.08 & 9.985 & 9.999 & 10.058 & 10.302 & 10.328 & 10.340 & 10.297 & 10.312 & 10.358 \\
\hline \multirow[t]{2}{*}{0.10} & 10.480 & 10.489 & 10.558 & 10.862 & 10.903 & 10.920 & 10.864 & 10.900 & 10.921 \\
\hline & \multicolumn{3}{|c|}{$\mathrm{L}_{\mathrm{f}} \times 10^{11}, \mathrm{~m}$} & \multicolumn{3}{|c|}{$\mathrm{L}_{\mathrm{f}} \times 10^{11}, \mathrm{~m}$} & \multicolumn{3}{|c|}{$\mathrm{L}_{\mathrm{f}} \times 10^{11}, \mathrm{~m}$} \\
\hline 0.0 & 5.58 & 5.72 & 5.80 & 5.58 & 5.72 & 5.80 & 5.58 & 5.72 & 5.80 \\
\hline 0.01 & 5.50 & 5.62 & 5.70 & 5.56 & 5.66 & 5.77 & 5.56 & 5.61 & 5.71 \\
\hline
\end{tabular}




\begin{tabular}{|c|c|c|c|c|c|c|c|c|c|}
\hline 0.02 & 5.46 & 5.59 & 5.66 & 5.51 & 5.62 & 5.72 & 5.53 & 5.58 & 5.70 \\
\hline 0.04 & 5.43 & 5.54 & 5.63 & 5.47 & 5.58 & 5.68 & 5.51 & 5.55 & 5.67 \\
\hline 0.06 & 5.39 & 5.51 & 5.58 & 5.44 & 5.55 & 5.65 & 5.48 & 5.53 & 5.63 \\
\hline 0.08 & 5.35 & 5.47 & 5.55 & 5.40 & 5.51 & 5.61 & 5.45 & 5.49 & 5.60 \\
\hline \multirow[t]{2}{*}{0.10} & 5.32 & 5.44 & 5.53 & 5.37 & 5.48 & 5.58 & 5.43 & 5.46 & 5.56 \\
\hline & \multicolumn{3}{|c|}{$\pi \times 10^{-8}, \mathrm{~Pa}$} & \multicolumn{3}{|c|}{$\pi \times 10^{-8}, \mathrm{~Pa}$} & \multicolumn{3}{|c|}{$\pi \times 10^{-8}, \mathrm{~Pa}$} \\
\hline 0.0 & 3.972 & 3.917 & 3.865 & 4.103 & 4.046 & 3.992 & 4.103 & 4.046 & 3.992 \\
\hline 0.01 & 4.106 & 3.894 & 3.701 & 4.078 & 3.942 & 3.930 & 3.963 & 3.868 & 3.839 \\
\hline 0.020 & 4.040 & 3.805 & 3.685 & 4.017 & 3.870 & 3.8218 & 3.825 & 3.762 & 3.760 \\
\hline 0.04 & 3.889 & 3.716 & 3.592 & 3.808 & 3.643 & 3.601 & 3.665 & 3.565 & 3.543 \\
\hline 0.06 & 3.719 & 3.599 & 3.477 & 3.592 & 3.442 & 3.414 & 3.511 & 3.463 & 3.371 \\
\hline 0.08 & 3.597 & 3.508 & 3.382 & 3.420 & 3.315 & 3.255 & 3.392 & 3.350 & 3.323 \\
\hline \multirow[t]{2}{*}{0.10} & 3.448 & 3.390 & 3.284 & 3.274 & 3.199 & 3.131 & 3.279 & 3.188 & 3.162 \\
\hline & \multicolumn{3}{|c|}{$\mathrm{V}_{\mathrm{f}} \times 10^{7}, \mathrm{~m}^{3}$} & \multicolumn{3}{|c|}{$\mathrm{V}_{\mathrm{f}} \times 10^{7}, \mathrm{~m}^{3}$} & \multicolumn{3}{|c|}{$V_{f} \times 10^{7}, m^{3}$} \\
\hline 0.01 & 2.625 & 3.070 & 3.533 & 2.909 & 3.214 & 3.239 & 3.173 & 3.397 & 3.469 \\
\hline 0.02 & 2.604 & 3.109 & 3.383 & 2.849 & 3.179 & 3.297 & 3.305 & 3.458 & 3.449 \\
\hline 0.04 & 2.606 & 2.980 & 3.260 & 2.944 & 3.352 & 3.458 & 3.315 & 3.519 & 3.614 \\
\hline 0.06 & 2.679 & 2.948 & 3.224 & 3.114 & 3.521 & 3.595 & 3.336 & 3.454 & 3.724 \\
\hline 0.08 & 2.672 & 2.873 & 3.165 & 3.220 & 3.515 & 3.705 & 3.302 & 3.415 & 3.467 \\
\hline \multirow[t]{2}{*}{0.10} & 2.753 & 2.892 & 3.140 & 3.303 & 3.512 & 3.730 & 3.286 & 3.550 & 3.623 \\
\hline & \multicolumn{3}{|c|}{$\tau \times 10^{13}, \mathrm{~s}$} & \multicolumn{3}{|c|}{$\tau \times 10^{13}, \mathrm{~s}$} & \multicolumn{3}{|c|}{$\tau \times 10^{13}, \mathrm{~s}$} \\
\hline 0.0 & 4.444 & 4.435 & 4.383 & 4.444 & 4.435 & 4.383 & 4.444 & 4.436 & 4.383 \\
\hline 0.01 & 4.989 & 4.599 & 4.261 & 4.738 & 4.516 & 4.581 & 4.468 & 4.313 & 4.334 \\
\hline 0.02 & 5.136 & 4.668 & 4.488 & 4.927 & 4.680 & 4.646 & 4.481 & 4.392 & 4.494 \\
\hline 0.04 & 5.407 & 5.053 & 4.486 & 5.117 & 4.787 & 4.779 & 4.764 & 4.557 & 4.635 \\
\hline 0.06 & 5.567 & 5.345 & 5.121 & 5.204 & 4.901 & 4.927 & 5.011 & 4.947 & 4.803 \\
\hline 0.08 & 5.839 & 5.695 & 5.431 & 5.363 & 5.167 & 5.084 & 5.320 & 5.249 & 5.035 \\
\hline \multirow[t]{2}{*}{0.10} & 5.979 & 5.920 & 5.713 & 5.532 & 5.431 & 5.320 & 5.612 & 5.374 & 5.408 \\
\hline & \multicolumn{3}{|c|}{$\left(\alpha / \mathrm{f}^{2}\right)_{\mathrm{cl} .} 10^{14}, \mathrm{~s}^{2} \mathrm{~m}^{-1}$} & \multicolumn{3}{|c|}{$\left(\alpha / \mathrm{f}^{2}\right)_{\mathrm{cl} .} 10^{14}, \mathrm{~s}^{2} \mathrm{~m}^{-1}$} & \multicolumn{3}{|c|}{$\left(\alpha / \mathrm{f}^{2}\right)_{\mathrm{cl} .} 10^{14}, \mathrm{~s}^{2} \mathrm{~m}^{-1}$} \\
\hline 0.01 & 7.703 & 7.251 & 6.801 & 7.386 & 7.161 & 7.403 & 6.961 & 6.775 & 6.929 \\
\hline 0.02 & 7.892 & 7.331 & 7.126 & 7.618 & 7.388 & 7.453 & 6.963 & 6.879 & 7.176 \\
\hline 0.04 & 8.269 & 7.886 & 7.667 & 7.882 & 7.509 & 7.630 & 7.385 & 7.112 & 7.373 \\
\hline 0.06 & 8.466 & 8.307 & 8.039 & 7.974 & 7.652 & 7.831 & 7.741 & 7.698 & 7.606 \\
\hline 0.08 & 8.834 & 8.804 & 8.492 & 8.179 & 8.028 & 8.038 & 8.187 & 8.134 & 8.359 \\
\hline \multirow[t]{2}{*}{0.10} & 9.002 & 9.115 & 8.905 & 8.398 & 8.398 & 8.372 & 8.609 & 8.284 & 8.486 \\
\hline & \multicolumn{3}{|c|}{$\mathrm{Sn}$} & \multicolumn{3}{|c|}{$\mathrm{Sn}$} & \multicolumn{3}{|c|}{$\mathrm{Sn}$} \\
\hline
\end{tabular}




\begin{tabular}{|l|l|l|l|l|l|l|l|l|l|}
\hline $\mathbf{0 . 0 1}$ & 1.40 & 1.24 & 1.25 & 6.96 & 2.26 & 4.60 & 5.65 & 1.18 & 1.50 \\
\hline $\mathbf{0 . 0 2}$ & 1.95 & 1.77 & 1.76 & 3.56 & 2.83 & 3.35 & 5.51 & 1.93 & 2.60 \\
\hline $\mathbf{0 . 0 4}$ & 3.93 & 3.56 & 3.54 & 7.18 & 5.70 & 6.77 & 11.1 & 3.89 & 5.25 \\
\hline $\mathbf{0 . 0 6}$ & 4.52 & 4.03 & 4.25 & 7.40 & 5.77 & 6.97 & 10.9 & 4.76 & 6.21 \\
\hline $\mathbf{0 . 0 8}$ & 4.84 & 4.57 & 4.47 & 7.29 & 6.27 & 7.31 & 10.5 & 5.66 & 6.57 \\
\hline $\mathbf{0 . 1 0}$ & 5.19 & 4.95 & 4.94 & 7.55 & 6.60 & 7.40 & 10.4 & 6.12 & 6.86 \\
\hline
\end{tabular}

Solvation number $\left(S_{n}\right)$ is used to decide the predominance of particular interaction in solution. At constant temperature the concentration of solute and dielectric constant of the solvent play an important role in determining the molecular interactions occurring in the solutions. Solvation number $\left(S_{n}\right)$ is the number of the solvent molecules attached to the central atoms or ions by their translational degree of freedom. Thus strength of solute-solvent interaction is reflected by solvation number $\left(\mathrm{S}_{\mathrm{n}}\right)$.

The presence of polar groups in the solute molecule enhances molecular interactions and the solvation phenomena. The plots of $S_{n}$ against $C$ at different $T$ are presented in Fig. 1 to 3 from which it is observed that $S_{n}$ increased nonlinearly with $C$. The positive value of $S_{n}$ with $C$ indicated appreciable solvation of SDSB-1 to 3 in THF. This confirmed the structure forming nature of the solutes in the solvent due to association between various components of solution. The nature of solute, concentration, temperature and position of functional group play an important role on the magnitude of solvation. $R_{m}$ increased linearly with $C$ and slightly decreased with $T$. $\pi$ decreased linearly with increasing $C$ and decreased with $T$, while $V_{f}$ increased linearly with increasing $C$ and $\mathrm{T}$ supporting effect of $\mathrm{C}$ and $\mathrm{T}$ on cohesive forces and hence molecular interactions.

Table-3 The least squares equations and correlation coefficients for SDSB-1 + THF

\begin{tabular}{|c|c|c|c|}
\hline \multirow{2}{*}{ Parameter } & \multicolumn{3}{|c|}{ Correlation equations (Correlation coefficients, $\gamma$ ) } \\
\hline & 303.15K & $308.15 K$ & 313.15K \\
\hline$\rho, \mathrm{kg} \cdot \mathrm{m}^{-3}$ & $\begin{array}{c}148.77 \mathrm{C}+888.71 \\
(0.985)\end{array}$ & $\begin{array}{c}150.36 \mathrm{C}+887.66 \\
(0.988)\end{array}$ & $\begin{array}{c}152.52 \mathrm{C}+882.74 \\
(0.987)\end{array}$ \\
\hline$\eta, \mathrm{mPa} \mathrm{s}$ & $\begin{array}{c}1.6811 \mathrm{C}+0.531 \\
(0.997)\end{array}$ & $\begin{array}{c}2.0519 \mathrm{C}+0.456 \\
(0.998)\end{array}$ & $\begin{array}{c}1.8807 \mathrm{C}+0.4194 \\
(0.985)\end{array}$ \\
\hline $\mathrm{U}, \mathrm{ms}^{-1}$ & $\begin{array}{c}351.4 \mathrm{C}+1275.1 \\
(0.997)\end{array}$ & $\begin{array}{c}338.03 \mathrm{C}+1248.1 \\
(0.993)\end{array}$ & $\begin{array}{c}328 \mathrm{C}+1234.1 \\
(0.989)\end{array}$ \\
\hline $\mathrm{Z} \times 10^{-6}, \mathrm{~kg} \cdot \mathrm{m}^{-2} \mathrm{~s}^{-1}$ & $\begin{array}{c}0.5058 \mathrm{C}+1.1332 \\
(0.993)\end{array}$ & $\begin{array}{c}0.4912 \mathrm{C}+1.1078 \\
(0.990)\end{array}$ & $\begin{array}{c}0.4792 \mathrm{C}+1.0897 \\
(0.989)\end{array}$ \\
\hline$\kappa_{\mathrm{S}} \times 10^{+10}, \mathrm{~Pa}^{-1}$ & $\begin{array}{c}-4.740 \mathrm{C}+6.918 \\
(-0.995)\end{array}$ & $\begin{array}{c}-4.891 C+7.228 \\
(-0.991)\end{array}$ & $\begin{array}{c}-5.006 \mathrm{C}+7.435 \\
(-0.988)\end{array}$ \\
\hline $\begin{array}{c}\mathrm{R}_{\mathrm{m}} \times 10^{4}, \\
\mathrm{~m}^{10 / 3} \mathrm{~s}^{1 / 3} \mathrm{~mol}^{-1}\end{array}$ & $\begin{array}{c}27.006 C+10.759 \\
(1)\end{array}$ & $\begin{array}{c}26.824 C+10.696 \\
(1)\end{array}$ & $\begin{array}{c}26.945 \mathrm{C}+10.716 \\
(1)\end{array}$ \\
\hline $\mathrm{b} \times 10^{5}, \mathrm{~m}^{3}$ & $\begin{array}{c}23.606 \mathrm{C}+9.7778 \\
(0.999)\end{array}$ & $\begin{array}{c}23.721 \mathrm{C}+9.802 \\
(0.999)\end{array}$ & $\begin{array}{c}23.845 \mathrm{C}+9.8413 \\
(0.999)\end{array}$ \\
\hline $\mathrm{L}_{\mathrm{f}} \times 10^{11}, \mathrm{~m}$ & $\begin{array}{c}-1.937 \mathrm{C}+5.5084 \\
(-0.994)\end{array}$ & $\begin{array}{c}-1.9699 \mathrm{C}+5.6301 \\
(-0.994)\end{array}$ & $\begin{array}{c}-1.8712 \mathrm{C}+5.705 \\
(-0.987)\end{array}$ \\
\hline$\pi \times 10^{-8}, \mathrm{~Pa}$ & $\begin{array}{c}-4.2011 \mathrm{C}+3.3207 \\
(-0.984)\end{array}$ & $\begin{array}{c}-2.5753 \mathrm{C}+3.1247 \\
(-0.993)\end{array}$ & $\begin{array}{c}-2.18 \mathrm{C}+2.9978 \\
(-0.983)\end{array}$ \\
\hline$V_{f} \times 10^{7}, \mathrm{~m}^{3}$ & $\begin{array}{c}-2.4293 \mathrm{C}+3.5203 \\
(-0.907)\end{array}$ & $\begin{array}{c}-6.3082 C+4.1744 \\
(-0.974)\end{array}$ & $\begin{array}{c}-8.4915 C+4.6824 \\
(-0.962)\end{array}$ \\
\hline$\tau \times 10^{13}, \mathrm{~s}$ & $\begin{array}{c}11.05 \mathrm{C}+4.9153 \\
(0.997)\end{array}$ & $\begin{array}{c}15.392 \mathrm{C}+4.4181 \\
(0.997)\end{array}$ & $\begin{array}{c}15.855 \mathrm{C}+4.158 \\
(0.998)\end{array}$ \\
\hline$\left(\alpha / \mathrm{f}^{2}\right)_{\mathrm{cl} .} 10^{14}, \mathrm{~s}^{2} \mathrm{~m}^{-1}$ & $\begin{array}{c}14.564 C+7.6085 \\
(0.994)\end{array}$ & $\begin{array}{c}21.801 \mathrm{C}+6.9906 \\
(0.997)\end{array}$ & $\begin{array}{c}22.936 \mathrm{C}+6.6533 \\
(0.997)\end{array}$ \\
\hline
\end{tabular}


Table-4 The least squares equations and correlation coefficients for SDSB-2 + THF

\begin{tabular}{|c|c|c|c|}
\hline \multirow{2}{*}{ Parameter } & \multicolumn{3}{|c|}{ Correlation equations (Correlation coefficients, $\gamma$ ) } \\
\hline & 303.15K & $308.15 K$ & 313.15K \\
\hline$\rho, \mathrm{kg} \cdot \mathrm{m}^{-3}$ & $\begin{array}{c}142.55 \mathrm{C}+886.72 \\
(0.996)\end{array}$ & $\begin{array}{c}135.56 \mathrm{C}+885.13 \\
(0.986)\end{array}$ & $\begin{array}{c}130.47 \mathrm{C}+884.29 \\
(0.988)\end{array}$ \\
\hline$\eta, \mathrm{mPas}$ & $\begin{array}{c}1.3101 \mathrm{C}+0.5013 \\
(0.989)\end{array}$ & $\begin{array}{c}1.3704 \mathrm{C}+0.4515 \\
(0.992)\end{array}$ & $\begin{array}{c}1.1403 \mathrm{C}+0.4434 \\
(0.997)\end{array}$ \\
\hline $\mathrm{U}, \mathrm{ms}^{-1}$ & $\begin{array}{c}348.44 C+1265.2 \\
(0.983)\end{array}$ & $\begin{array}{c}343.12 \mathrm{C}+1241.7 \\
(0.995)\end{array}$ & $\begin{array}{c}337.32 \mathrm{C}+1220.2 \\
(0.987)\end{array}$ \\
\hline $\mathrm{Z} \times 10^{-6}, \mathrm{~kg} \cdot \mathrm{m}^{-2} \mathrm{~s}^{-1}$ & $\begin{array}{c}0.489 \mathrm{C}+1.1222 \\
(0.994)\end{array}$ & $\begin{array}{c}0.4756 \mathrm{C}+1.0991 \\
(0.992)\end{array}$ & $\begin{array}{c}0.4526 \mathrm{C}+1.0793 \\
(0.989)\end{array}$ \\
\hline$\kappa_{\mathrm{S}} \times 10^{+10} \mathrm{~Pa}^{-1}$ & $\begin{array}{c}-4.7699 C+7.0411 \\
(-0.988)\end{array}$ & $\begin{array}{c}-4.9178 \mathrm{C}+7.3228 \\
(-0.992)\end{array}$ & $\begin{array}{c}-5.0792 C+7.5913 \\
(-0.986)\end{array}$ \\
\hline $\begin{array}{c}\mathrm{R}_{\mathrm{m}} \times 10^{4} \\
\mathrm{~m}^{10 / 3} \mathrm{~s}^{1 / 3} \mathrm{~mol}^{-1}\end{array}$ & $\begin{array}{c}32.223 \mathrm{C}+8.8078 \\
(0.999)\end{array}$ & $\begin{array}{c}32.292 \mathrm{C}+8.7662 \\
\text { (1) }\end{array}$ & $\begin{array}{c}32.255 \mathrm{C}+8.7225 \\
(0.999)\end{array}$ \\
\hline $\mathrm{b} \times 10^{5}, \mathrm{~m}^{3}$ & $\begin{array}{c}28.527 \mathrm{C}+8.0155 \\
(1)\end{array}$ & $\begin{array}{c}28.673 \mathrm{C}+8.0232 \\
\text { (1) }\end{array}$ & $\begin{array}{c}28.872 C+8.0328 \\
\text { (1) }\end{array}$ \\
\hline $\mathrm{L}_{\mathrm{f}} \times 10^{11}, \mathrm{~m}$ & $\begin{array}{c}-1.9178 C+5.556 \\
(-0.992)\end{array}$ & $\begin{array}{c}-1.9178 C+5.6658 \\
(-0.992)\end{array}$ & $\begin{array}{c}-1.9863 \mathrm{C}+5.771 \\
(-0.995)\end{array}$ \\
\hline$\pi \times 10^{-8}, \mathrm{~Pa}$ & $\begin{array}{c}-9.331 \mathrm{C}+4.1814 \\
(-0.998)\end{array}$ & $\begin{array}{c}-8.5679 C+4.0118 \\
(-0.992)\end{array}$ & $\begin{array}{c}-9.000 \mathrm{C}+3.990 \\
(-0.995)\end{array}$ \\
\hline $\mathrm{V}_{\mathrm{f}} \times 10^{7}, \mathrm{~m}^{3}$ & $\begin{array}{c}5.92 \mathrm{C}+2.7308 \\
(0.993)\end{array}$ & $\begin{array}{c}3.145 \mathrm{C}+3.2258 \\
(0.972)\end{array}$ & $\begin{array}{c}5.265 \mathrm{C}+3.2351 \\
(0.957)\end{array}$ \\
\hline$\tau \times 10^{13}, \mathrm{~s}$ & $\begin{array}{c}8.2156 \mathrm{C}+4.721 \\
(0.985)\end{array}$ & $\begin{array}{c}9.4545 \mathrm{C}+4.425 \\
(0.985)\end{array}$ & $\begin{array}{c}7.9701 \mathrm{C}+4.4777 \\
(0.994)\end{array}$ \\
\hline$\left(\alpha / \mathrm{f}^{2}\right)_{\mathrm{cl} .} 10^{14}, \mathrm{~s}^{2} \mathrm{~m}^{-1}$ & $\begin{array}{c}1.0499 \mathrm{C}+0.7361 \\
(0.984)\end{array}$ & $\begin{array}{c}1.2707 \mathrm{C}+6.7033 \\
(0.979)\end{array}$ & $\begin{array}{c}1.0575 \mathrm{C}+0.724 \\
(0.990)\end{array}$ \\
\hline
\end{tabular}


Table-5 The least squares equations and correlation coefficients for SDSB-3 + THF

\begin{tabular}{|c|c|c|c|}
\hline \multirow{2}{*}{ Parameter } & \multicolumn{3}{|c|}{ Correlation equations (Correlation coefficients, $\gamma$ ) } \\
\hline & 303.15K & $308.15 K$ & $313.15 K$ \\
\hline$\rho, \mathrm{kg} \cdot \mathrm{m}^{-3}$ & $\begin{array}{c}150.93 \mathrm{C}+886.19 \\
(0.988)\end{array}$ & $\begin{array}{c}146.08 \mathrm{C}+884.59 \\
(0.982)\end{array}$ & $\begin{array}{c}138.05 \mathrm{C}+882.88 \\
(0.999)\end{array}$ \\
\hline$\eta, \mathrm{mPas}$ & $\begin{array}{c}1.7148 \mathrm{C}+0.4512 \\
(0.997)\end{array}$ & $\begin{array}{c}1.6751 \mathrm{C}+0.4295 \\
(0.994)\end{array}$ & $\begin{array}{c}1.5592 \mathrm{C}+0.4189 \\
(0.985)\end{array}$ \\
\hline $\mathrm{U}, \mathrm{ms}^{-1}$ & $\begin{array}{c}214.25 C+1264 \\
(0.998)\end{array}$ & $\begin{array}{c}249.97 \mathrm{C}+1253.2 \\
(0.995)\end{array}$ & $\begin{array}{c}265.7 \mathrm{C}+1229.8 \\
(0.997)\end{array}$ \\
\hline $\mathrm{Z} \times 10^{-6}, \mathrm{~s}^{-1}$ Skg.m ${ }^{-2}$ & $\begin{array}{c}0.3879 \mathrm{C}+1.12 \\
(0.997)\end{array}$ & $\begin{array}{c}0.4033 C+1.1088 \\
(0.995)\end{array}$ & $\begin{array}{c}0.4145 \mathrm{C}+1.0854 \\
(0.999)\end{array}$ \\
\hline$\kappa_{\mathrm{S}} \times 10^{+10}, \mathrm{~Pa}^{-1}$ & $\begin{array}{c}-3.4674 C+7.0605 \\
(-0.997)\end{array}$ & $\begin{array}{c}-3.8934 \mathrm{C}+7.1948 \\
(-0.997)\end{array}$ & $\begin{array}{c}-4.2247 C+7.4853 \\
(-0.999)\end{array}$ \\
\hline $\begin{array}{c}\mathrm{R}_{\mathrm{m}} \times 10^{4}, \\
\mathrm{~m}^{10 / 3} \mathrm{~s}^{1 / 3} \mathrm{~mol}^{-1}\end{array}$ & $\begin{array}{c}31.711 \mathrm{C}+8.8118 \\
\text { (1) }\end{array}$ & $\begin{array}{c}31.947 \mathrm{C}+8.801 \\
(0.999)\end{array}$ & $\begin{array}{c}32.039 C+8.7633 \\
\text { (1) }\end{array}$ \\
\hline $\mathrm{b} \times 10^{5}, \mathrm{~m}^{3}$ & $\begin{array}{c}28.434 \mathrm{C}+8.0206 \\
\text { (1) }\end{array}$ & $\begin{array}{c}28.612 \mathrm{C}+8.034 \\
\text { (1) }\end{array}$ & $\begin{array}{c}28.803 C+8.0488 \\
\text { (1) }\end{array}$ \\
\hline $\mathrm{L}_{\mathrm{f}} \times 10^{11}, \mathrm{~m}$ & $\begin{array}{c}-1.4027 C+5.566 \\
(-0.993)\end{array}$ & $\begin{array}{c}-1.589 C+5.619 \\
(-0.994)\end{array}$ & $\begin{array}{c}-1.6849 C+5.7321 \\
(-0.998)\end{array}$ \\
\hline$\pi \times 10^{-8}, \mathrm{~Pa}$ & $\begin{array}{c}-7.4233 C+3.9894 \\
(-0.992)\end{array}$ & $\begin{array}{c}-7.2373 \mathrm{C}+3.9066 \\
(-0.993)\end{array}$ & $\begin{array}{c}-7.4444 \mathrm{C}+3.8843 \\
(-0.986)\end{array}$ \\
\hline $\mathrm{V}_{\mathrm{f}} \times 10^{7}, \mathrm{~m}^{3}$ & $\begin{array}{c}-45.485 C^{2}+5.7171 C \\
+3.1585(-0.846)\end{array}$ & $\begin{array}{c}-52.841 C^{2}+7.5415 C \\
+3.2313(-0.958)\end{array}$ & $\begin{array}{c}-74.325 C^{2}+10.492 C \\
+3.3268(-0.933)\end{array}$ \\
\hline$\tau \times 10^{13}, \mathrm{~s}$ & $\begin{array}{c}13.166 \mathrm{C}+4.262 \\
(0.995)\end{array}$ & $\begin{array}{c}12.779 \mathrm{C}+4.145 \\
(0.989)\end{array}$ & $\begin{array}{c}12.272 \mathrm{C}+4.195 \\
(0.979)\end{array}$ \\
\hline$\left(\alpha / \mathrm{f}^{2}\right)_{\mathrm{cl} .} 10^{14}, \mathrm{~s}^{2} \mathrm{~m}^{-1}$ & $\begin{array}{c}19.049 \mathrm{C}+6.6568 \\
(0.994)\end{array}$ & $\begin{array}{c}18.397 \mathrm{C}+6.53 \\
(0.987)\end{array}$ & $\begin{array}{c}18.05 \mathrm{C}+6.7133 \\
(0.979) \mathrm{S}\end{array}$ \\
\hline
\end{tabular}




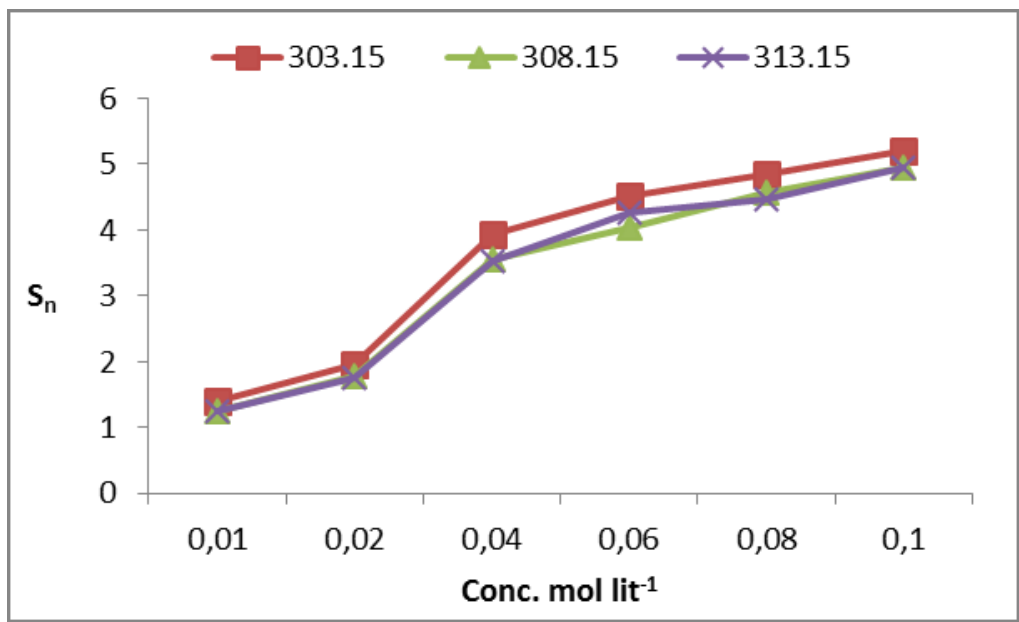

Figure 1 The plots of $S_{n}$ against $C$ for SDSB-1 in THF at 303.15, 308.15 and 313.15 K

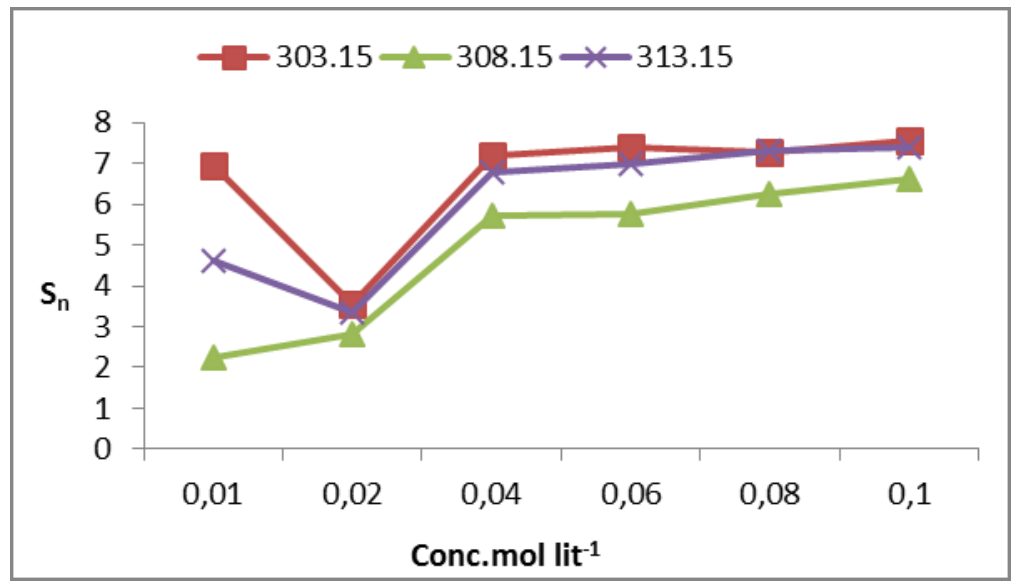

Figure 2 The plots of $S_{n}$ against $C$ for SDSB-2 in THF at 303.15, 308.15 and $313.15 \mathrm{~K}$

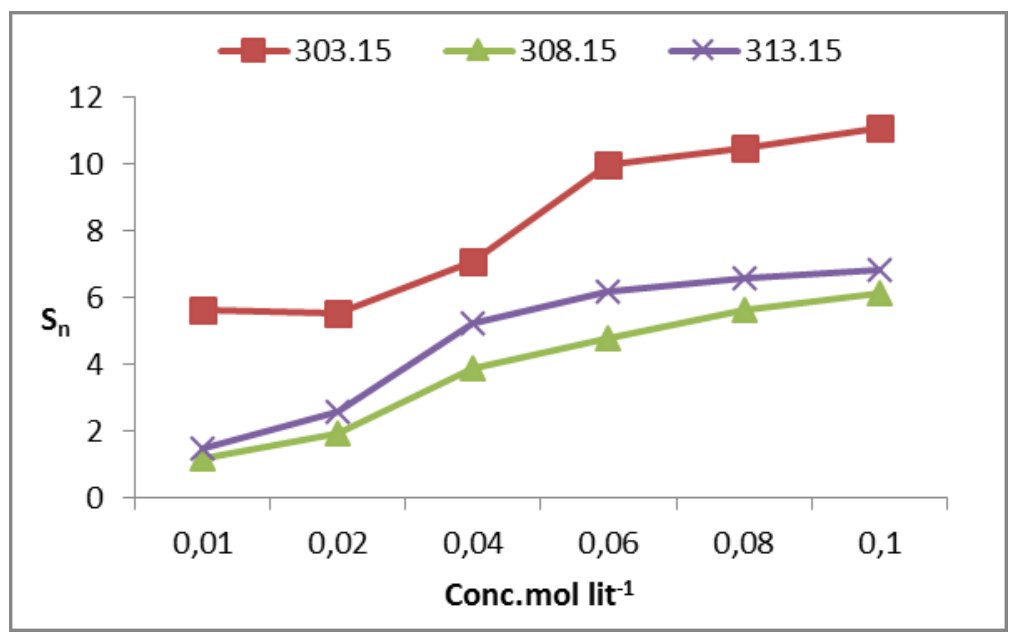

Figure 3 The plots of $S_{n}$ against $C$ for SDSB-3 in THF at 303.15, 308.15 and 313.15 K 


\section{CONCLUSION}

Studied acoustical parameters supported existences of strong molecular interactions in THFSchiff bases solution at different temperatures. The non linear increase of $S_{n}$ with $C$ suggested competing solvent-solute and solute-solute interaction in the solutions. At higher concentration and low temperature solute-solvent interactions are predominant over solute-solute interactions. The strength of solute-solvent interaction is given in order SDSB-3 $>$ SDSB-2 > SDSB-1.The strength of interaction is affected by concentration, temperature, nature and position of functional group.

\section{ACKNOWLEDGEMENTS}

The authors are thankful to Department of Chemistry, Saurashtra University, Rajkot, for instrumentation and research facilities.

\section{Reference}

[1] S. Patai The chemistry of the carbon-nitrogen double bond. John-Wiley and Sons. Ltd. London (1970).

[2] V. K. Aghera, R. Y. Ghumara, P. H. Parsania, J. Sci. Ind. Res. 74 (2015) 43-47.

[3] B. J. Gangani, P. H. Parsania, Spectroscopy Letters 40 (2007) 97-112.

[4] D. N. Dhar, C. N. Taploo, J. Sci. Ind. Res. 41(8) (1982) 501-506.

[5] Y. B. Zemede, S. Anadakumar, Int. J. Chem. Tech. Res. 7(1) (2014) 279-286.

[6] P. Panneerselvam, B. A. Rather, D. R. Reddy, N. R. Kumar, Euro. J. Med. Chem. 44 (2009) 2328-2333.

[7] S. H. Abdel-Hafez, Phosphorus, sulfur, and silicon. 178 (2003) 2563-2579.

[8] N.B. Patel, J.C. Patel, Arabian J. Chem. 4 (2011) 403-411.

[9] M. M. Kamel, H.L. Ali, M. M. Anawar, N. A. Mohamed, A. M. Soliman, Euro. J. Med. Chem.,45 (2010) 572-580.

[10]H. Naeimi, J. Safari, A. Heidarnezhad, Dyes Pigm. 73, (2007) 251-253.

[11]S. Baluja, A. Solanki, N. Kachhadia, Russian J. Phy. Chem. A, 81(5) (2007) 742-746.

[12] V. K. Syal, S. K. Thakur, S. Chauhan, P. Sharma, Int. J. of Thermo physics, 26(3) (2005) 807826.

[13]U. G. Pathak, J.V. Patel, P. H. Parsania, J. Solution. Chem. 41 (2012) 755-765.

[14]U. D. Chapke, B. P. Meshram, P. S. Agrawal, B. N. Berad, Int. J. Emerging Technologies in Computational and Applied Sciences, 4(3) (2013) 269-275.

[15]B. J. Gangani, P. H. Parsania, J. Pure. Appl. Ultrasonic, 30 (2008) 90-96.

[16]B. J. Gangani, P. H. Parsania, Int. J. Chem. Phy. Astro., 6 (2015) 16-23.

[17]B. J. Gangani, P. H. Parsania, J. Chem. Pharm. Res., 6(11) (2014) 243-247.

[18]B. J. Gangani, P. H. Parsania, Der Chemica Sinica., 6(5) (2015) 28-35.

[19]K. Saravankumar, T. G. Lavanya, R. Baskaran, T. R. Kubendran, J. Iran. Chem. Soc., 9(2012) 277-283.

[20] J. D. Pandy, A. Shukla, R.D. Rai, K. J. Mishra, J. Chem. Eng. Data, 34 (1989) 29-31.

[21]K. C. Patil, V. D. Umare, Int. J. Res. Pure \& Appl. Phys., 2(4) (2012) 25-27.

[22]B. J. Gangani, P. H. Parsania, J. Indian Chem. Soc., 86 (2009) 942-949. 
[23]B. J. Gangani, P. H. Parsania, Archives of Applied Science Research, 7(1) (2015) 10-14.

[24]J. A. Riddick, W. B. Bunger; T. Sakano, Organic Solvents Physical Properties and Methods of Purification, Vol. II, $4^{\text {th }}$ ed., Wiley-Interscience Publication, John Wiley, New York, (1986).

[25]R. Premalatha, N. Santhi, Int. Lett. Chem., Phys. Astro. 14(1) (2014) 53-64.

[26] N. Vekariya, J. Movaliya, S. Baluja, Iran. J. Chem. Chem. Eng., 27(1) (2008) 129-135. 